\title{
Hospital-Acquired Acute Hyponatremia and Parenteral Fluid Administration in Children
}

\author{
Christine Koczmara, Sylvia Hyland, and Julie Greenall
}

Note to Readers: Contributions to this column are prepared by the Institute for Safe Medication Practices Canada (ISMP Canada). The article presented here uses, with permission, information originally published in ISMP Canada Safety Bulletin 2009;9(7).

Future bulletins from ISMP Canada that have particular relevance to hospital pharmacists will be published in the CSHP eBulletin, a semimonthly newsletter that is posted at the CSHP website (http://cshp.ca/productsServices/eob/index_e.asp). The editorial board, publisher, and readers of CJHP thank ISMP Canada for its contributions to the Journal over the past 10 years.

\section{INTRODUCTION}

$P$ arenteral fluids administered for the purpose of hydration have not traditionally been viewed with the same rigour as medications. These fluids are usually distributed through the materials management division of hospital operations. In addition, fluids are often not reviewed by pharmacists as part of pharmaceutical care activities. Fluid and electrolyte management is a crucial aspect of overall patient management, and there is an opportunity for pharmacists to offer greater support in this area.

This article highlights the issue of hospital-acquired acute hyponatremia in children. ${ }^{1}$ Acute hyponatremia is defined as a decline in serum sodium within a 48-hour period to less than $130 \mathrm{mmol} / \mathrm{L}$, an abrupt change that can lead to cerebral edema as a result of electrolyte-free water moving into the brain cells.

Various literature reports, ${ }^{2-7}$ pediatric inquests, ${ }^{8}$ and a recent newsletter from the US Institute for Safe Medication Practices ${ }^{9}$ have highlighted cases of acute hyponatremia leading to the in-hospital deaths of children. The National Patient Safety Agency in the United Kingdom has identified hospitalacquired hyponatremia in children as a major patient safety issue. Several safety alerts and guidelines for the administration of fluids to children have been published internationally. ${ }^{10-13}$ The Canadian Medical Protective Association recently highlighted a case of hospital-acquired hyponatremia in a child. ${ }^{14} \mathrm{~A}$ provincial coroner identified 6 pediatric deaths related to acute hyponatremia in hospital settings over a 10-year period and provided a guideline for practitioners administering parenteral fluids to children. ${ }^{15}$
Two pediatric deaths due to acute hyponatremia associated with IV administration of hypotonic solutions have been voluntarily reported to ISMP Canada. ${ }^{1}$ Information from these reports is shared to enhance understanding of the potential for fatal hyponatremia in children.

\section{INCIDENT REPORTS}

\section{Case 1}

A 4-year-old child who weighed about $15 \mathrm{~kg}$ underwent tonsillectomy as day surgery. No abnormalities were noted during a preadmission assessment the day before the surgery. The tonsillectomy was performed under general anesthesia, and the child was mechanically ventilated during the procedure. The child received a total of $250 \mathrm{~mL}$ of normal saline IV $(0.9 \%$ sodium chloride). After the procedure, an infusion of $3.3 \%$ dextrose and $0.3 \%$ sodium chloride solution (referred to herein as " $2 / 3$ and $1 / 3$ ") $)^{*}$ was ordered for IV administration at 55 $\mathrm{mL}$ per hour. Oral intake of fluids was also encouraged. The child was transferred to a patient care area with orders to be discharged home when drinking well.

\footnotetext{
*The combination of $3.3 \%$ dextrose and $0.3 \%$ sodium chloride (known as $2 / 3$ and $1 / 3$ ) contains only $51 \mathrm{mmol} / \mathrm{L}$ of sodium. Outside the body, the osmolarity of the solution is 269 $\mathrm{mOsmol} / \mathrm{L}$ (sodium and dextrose combined). Once the solution is infused, however, the dextrose is rapidly metabolized, which leaves two-thirds of the solution $(667 \mathrm{~mL}$ ) as electrolyte-free water and renders the solution extremely hypotonic.
} 
Shortly after arriving in the patient care area, the child experienced several episodes of vomiting. Oral intake of clear fluids over the next several hours was about $200 \mathrm{~mL}$. The child was kept in hospital, and the IV administration of " $2 / 3$ and $1 / 3$ " was continued as originally ordered over the rest of the day and night. The child voided several times, but the amount was unknown. Overnight, the child became incontinent and was noted to be drowsy. Toward the next morning, the child had several seizures, which were treated initially with lorazepam and later with phenobarbital. Blood testing indicated a sodium level below $120 \mathrm{mmol} / \mathrm{L}$. The IV solution was changed to sodium chloride $3 \%$, and the child was transferred to a regional pediatric centre. The child died shortly thereafter. The cause of death was severe cerebral edema with brain herniation due to acute hyponatremia.

\section{Case 2}

A previously healthy 3-year-old child was brought to an emergency department with a 1-day history of vomiting and diarrhea. The child's pulse was more than 125 beats per minute; blood pressure was $85 / 60 \mathrm{~mm} \mathrm{Hg}$. The child's mucosal membranes were dry and the eyes sunken. Laboratory testing indicated normal serum electrolytes, elevated blood urea nitrogen (BUN), and normal creatinine; a urine test was positive for ketones. In the emergency department, the child received 2 boluses of normal saline by IV administration, totalling about $450 \mathrm{~mL}$. Follow-up blood work revealed that the sodium level was $138 \mathrm{mmol} / \mathrm{L}$ and $\mathrm{BUN}$ had decreased to within normal limits. The child was admitted, and " $2 / 3$ and $1 / 3$ " was administered at $130 \mathrm{~mL}$ per hour IV. Over the course of the next 12 hours (through the evening and overnight), the child voided about $110 \mathrm{~mL}$ urine in total and received over 1.5 litres of " $2 / 3$ and $1 / 3$ ". The child's nausea continued.

The next day, the child voided once, but the amount was not determined or recorded. Shortly thereafter, the child experienced incontinence of urine and seemed to be sleepy. A few hours later, the child appeared lethargic and rigid. The infusion was stopped, and blood tests revealed a sodium level below 120 $\mathrm{mmol} / \mathrm{L}$ and lower-than-normal levels of potassium, BUN, and creatinine. The child experienced a seizure and was treated with lorazepam. Hypertonic saline was ordered, but none was available, so mannitol was administered IV, followed by a bolus of normal saline. Because of continued seizure activity and oxygen desaturation, the child was intubated and ventilated. Shortly thereafter, the child experienced cardiac arrest and could not be resuscitated. The cause of death was cerebral edema due to acute hyponatremia.

\section{BACKGROUND INFORMATION ABOUT ACUTE HYPONATREMIA}

Hyponatremia can occur if there is a disproportionate loss of sodium such as occurs with primary kidney disease or conditions that affect the ability of the kidneys to conserve sodium. It can also occur because of a disproportionate gain of electrolyte-free water in the vascular compartment, also known as dilutional hyponatremia or water intoxication. The increased ratio of free water to sodium in the vascular space will cause the water to move from this extracellular compartment into the intracellular compartment until osmolality is equalized-free water will enter body cells (i.e., brain cells) and cellular edema will result.

In acute hyponatremia, the brain cells are unable to compensate for the rapid decrease in serum osmolality; as such, minor increases in electrolyte-free water can lead to disproportionately large increases in intracranial pressure due to swelling of the brain cells. ${ }^{2-4}$ Acute hyponatremia can be fatal for both children and adults; however, children are more vulnerable to the effects of fluid and electrolyte imbalance. Children exhibit symptoms more quickly than adults in response to abnormal sodium levels because there is less room for the brain cells to swell (the brain reaches its adult size by the time the child is 6 years old, but the skull does not reach adult size until a person is 16 years of age). ${ }^{4}$

The early signs and symptoms of acute hyponatremia and rising intracranial pressure are often nonspecific (nausea, vomiting, headache, and decreasing level of consciousness) and thus may be attributed to other causes, such as the postoperative effects of anesthetics, medications administered for pain, or the presenting illness. A rapid decline in serum sodium levels combined with symptoms of increased intracranial pressure is a medical emergency, as further increases in brain-cell swelling can cause seizures, respiratory depression, coma, irreversible brain damage, or brain herniation and death.

\section{DISCUSSION}

There appears to be general consensus that isotonic fluids such as normal saline should be used for children during surgery and in the treatment of moderate to severe hypovolemia; however, there is debate as to which solution is the best choice for maintenance of hydration..$^{2,7,16-28}$ Pediatric experts are questioning the widespread use of hypotonic solutions for parenteral maintenance based on a formula that was developed more than 50 years ago. ${ }^{29}$ The formula is derived from minimum free-water requirements based on caloric expenditure per kilogram of body weight. Experts argue that this formula overestimates maintenance requirements for a variety of reasons; most importantly, the formula presumes normal excretion of free water by the kidneys and thus does not take into account antidiuretic hormone released in response to nonosmotic stimuli, a process that was identified since the original development of the formula and that is commonly seen in children being cared for in hospital. In one recent study, a key factor in the development of hospital-acquired hyponatremia was the use of hypotonic maintenance solutions. ${ }^{30} \mathrm{~A}$ variety of studies, including randomized trials, are answering 
questions about the use of maintenance fluids for children..$^{30-32}$ Experts do agree, however, that there is no single IV solution that is ideal for all children.

\section{Recommendations and Considerations for Pharmacists}

Many Canadian pediatric centres have recognized hospital-acquired hyponatremia as an important issue that merits attention and have revised (or are in the process of revising) their practice guidelines and management of fluids and electrolytes accordingly. ${ }^{33-35}$ Pharmacists are urged to advocate for and participate in reviewing and updating the guidelines for fluid and electrolyte therapy for children within their respective organizations to ensure that these guidelines correspond with those of the regional pediatric referral centre. Readers are encouraged to consult the ISMP Canada Safety Bulletin $^{1}$ for an overview of suggested considerations for such guidelines.

Monitoring of parenteral fluid and electrolyte administration, particularly in pediatric patients, is a logical extension of the pharmaceutical care role. It is hoped that this article will serve as an alert to all pharmacists and will result in increased attention to fluid-use processes.

\section{References}

1. Hospital-acquired acute hyponatremia: two reports of pediatric deaths. ISMP Canada Saf Bull 2009 [cited 2009 Oct 30];9(7). Available from: http://www.ismp-canada.org/download/safetyBulletins/ ISMPCSB2009-7-HospitalAcquiredAcuteHyponatremia.pdf

2. Hoorn EJ, Geary D, Robb M, Halperin ML, Bohn D. Acute hyponatremia related to intravenous fluid administration in hospitalized children: an observational study. Pediatrics 2004;113(5):1279-1284.

3. Moritz ML, Ayus JC. Prevention of hospital-acquired hyponatremia: a case for using isotonic saline. Pediatrics 2003;111(2):227-230.

4. Arieff AI, Ayus JC, Fraser CL. Hyponatraemia and death or permanent brain damage in healthy children. BMJ 1992;304(6836):1218-1222.

5. McRae RG, Weissburg AJ, Chang KW. Iatrogenic hyponatremia: a cause of death following pediatric tonsillectomy. Int J Pediatr Otorhinolaryngol 1994;30(3):227-232.

6. Auroy Y, Benhamou D, Péquignot F, Jougla E, Lienhart A. Hyponatraemia-related death after paediatric surgery still exists in France. BrJ Anaesth 2008;101(5):741.

7. Duke T, Kinney S, Waters K. Hyponatraemia and seizures in oncology patients associated with hypotonic intravenous fluids. J Paediatr Child Health 2005;41(12):685-686.

8. Progress hearing in the matter of: hyponatraemia related deaths held at the Hilton Hotel on Friday 30th May 2008. Belfast (Ireland): Inquiry into Hyponatraemia-Related Deaths; [cited 2009 Aug 29]. Available from: http://www.ihrdni.org/hearing-30may08-transcript.pdf

9. Plain D5W or hypotonic saline solutions post-op could result in acute hyponatremia and death in health children. ISMP Med Saf Alert 2009 Aug 13 [cited 2009 Sep 15];14(16):1-4. Available from: http:// www.ismp.org/Newsletters/acutecare/articles/20090813.asp

10. Patient safety alert 22: reducing the risk of hyponatraemia when administering intravenous infusions to children. London (UK): National Patient Safety Agency; 2007 Mar 28 [cited 2009 Sept 24]. Available from: http://www.nrls.npsa.nhs.uk/EasySiteWeb/getresource.axd?Asset ID $=60073 \&$ type $=$ full\&servicetype $=$ Attachment
11. Background information: Patient safety alert 22: Reducing the risk of hyponatraemia when administering intravenous infusions to children. London (UK): National Patient Safety Agency; 2007 Mar [cited 2009 Sep 24]. Available from: http://www.nrls.npsa.nhs.uk/EasySiteWeb/ getresource.axd?AssetID=60071\&type=full\&servicetype=Attachment

12. Paediatric parenteral fluid therapy ( 1 month $-16 \mathrm{yrs})$ : initial management guideline [wall chart]. Belfast (Ireland): Government of Northern Ireland, Department of Health, Social Services and Public Safety; 2007 Sep [cited 2009 Sep 18]. Available from: http://www.dhsspsni. gov.uk/hsc_sqsd_20-07_wallchart.pdf

13. Ellis D. Women and Children's Directorate: management of symptomatic hyponatraemia. Glasgow (Scotland): Royal Hospital for Sick Children and Queen Mother's Hospital; 2008 May [cited 2009 Sep 18]. Available from: http://www.clinicalguidelines.scot.nhs.uk/YORDIV004\%20Symptomatic\%20Hyponatraemia\%20approved $\% 20$ pdf $\%$ 20new.pdf

14. Hyponatremia in children. Ottawa $(\mathrm{ON})$ : Canadian Medical Protective Association; 2008 Dec [cited 2009 Sep 16]. Available from: http://www.cmpa-acpm.ca/cmpapd04/docs/resource_files/infoletters/ 2008/pdf/com_il0840_1-e.pdf

15. Report of the Paediatric Death Review Committee and Deaths Under Five Committee. Toronto (ON): Office of the Chief Coroner Province of Ontario; 2007 Jun [cited 2009 Sep 11]. p. 19-20. Available from: http://www.oacas.org/pubs/external/pdrcannualreportfinal07june04.pdf

16. Neville KA, Verge CF, O’Meara MW, Walker JL. High antidiuretic hormone levels and hyponatremia in children with gastroenteritis. Pediatrics 2005;116(6):1401-1407.

17. Taylor D, Durward A. Pouring salt on troubled waters. Arch Dis Child 2004;89(5):411-414.

18. Choong K, Kho ME, Menon K, Bohn D. Hypotonic versus isotonic saline in hospitalised children: a systematic review. Arch Dis Child 2006;91(10):828-835.

19. Skippen P, Adderley R, Bennett M, Cogswell A, Froese N, Seear M, et al. Iatrogenic hyponatremia in hospitalized children: can it be avoided? Paediatr Child Health 2008;13(6):502-506.

20. Moritz ML, Ayus JC. Preventing neurological complications from dysnatremias in children. Pediatr Nephrol 2006;21(7):1048-1049.

21. Coulthard MG. Will changing maintenance intravenous fluid from $0.18 \%$ to $045 \%$ saline do more harm than good? Arch Dis Child 2008;93(4):335-340. Erratum in: Arch Dis Child 2008;93(12):1079.

22. Hatherill M. Rubbing salt in the wound. The case against isotonic parenteral maintenance solution. Arch Dis Child 2004;89(5):414-418.

23. Holliday MA, Segar WE. Reducing errors in fluid therapy management. Pediatrics 2003;111(2):424-425.

24. Holliday MA, Friedman AL, Segar WE, Chesney R, Finberg L. Acute hospital-induced hyponatremia in children: a physiological approach. $J$ Pediatr 2004;145(5):584-587.

25. Holliday MA, Ray PE, Friedman AL. Fluid therapy for children: facts, fashions and questions. Arch Dis Child 2007;92(6):546-550.

26. Beck CE. Hypotonic versus isotonic maintenance intravenous fluid therapy in hospitalized children: a systematic review. Clin Pediatr 2007;46(9):764-770.

27. Nevelle KA, Verge CF, Rosenberg AR, O'Meara MW, Walker JL. Isotonic is better than hypotonic saline for intravenous rehydration of children with gastroenteritis: a prospective randomised study. Arch Dis Child 2006;91(3):225-232.

28. Shafiee MA, Bohn D, Hoorn EJ, Halperin ML. How to select optimal maintenance intravenous fluid therapy. Am J Med 2003;96(8):601-610.

29. Holliday MA, Segar WE. The maintenance need for water in parenteral fluid therapy. Pediatrics 1957;18:823-832.

30. Montañana PA, Modesto i Alapont V, Ocón AP, López PO, López Prats JL, Toledo Parreño JD. The use of isotonic fluid as maintenance therapy prevents iatrogenic hyponatremia in pediatrics: a randomized, controlled open study. Pediatr Crit Care Med 2008;9(6):589-597. 
31. Au AK, Ray PE, McBryde KD, Newman KD, Weinstein SL, Bell MJ. Incidence of postoperative hyponatremia and complications in criticallyill children treated with hypotonic and normotonic solutions. J Pediatr 2008;152(1):33-38.

32. Yung M, Keeley S. Randomized controlled trial of intravenous maintenance fluids. J Paediatr Child Health 2009;45(1-2):9-14.

33. Hospital-wide patient care clinical practice guideline. Fluid and electrolyte administration in children. Toronto $(\mathrm{ON})$ : Hospital for Sick Children; 2007 Dec 4 [cited 2009 Sep 14]. Available from: http:// www.cags-accg.ca/docs/Fluid_and_Electrolyte_Administration__CPG.pdf

34. Fluid management in hospitalized children: preventing iatrogenic hyponatremia. Version 1. Vancouver (BC): BC Children's Hospital; 2008 Apr 11 [cited 2009 Sep 14]. Available from: http://www. childhealthbc.ca/resources/category/11-fluid-management-inhospitalised-children?download=21\%3Afluid-management-guileline
35. Hurdowar A, Urmson L, Bohn D, Geary D, Laxer R, Stevens P. Compliance with a pediatric clinical practice guideline for intravenous fluid and electrolyte administration. Healthc Q 2009;12 Spec No. Patient:129-134

Christine Koczmara, RN, BSc, is a Senior Analyst with the Institute for Safe Medication Practices Canada, Toronto, Ontario.

Sylvia Hyland, RPh, BScPhm, MHSC, is Vice-President and Chief Operating Officer of ISMP Canada, Toronto, Ontario.

Julie Greenall, RPh, BScPhm, MHSc, FISMPC, is a Project Leader with the Institute for Safe Medication Practices Canada, Toronto, Ontario.

ISMP Canada homepage: www.ismp-canada.org

e-mail: info@ismp-canada.org

Medication incidents (including near misses) can be reported

to ISMP Canada in 1 of 2 ways:

- through the secure web portal at http://www.ismp-canada.org/ err_report.htm

- by telephone at 416.733 .3131 or toll-free at 1.866.544.7672 (1.866.54.ISMPC)

\section{CISADL 2009}

Order your copy of the 2009 Canadian Investigational \& Special Access Drug List today!

Please use the CSHP order form found online to place your order:

\section{http://www.cshp.ca/productsServices/otherPublications/canadianlnvestigational e.asp}

The CSADC is a coencilation of drugs that are currenty not marketed in Canada and may hawe Imestigational or Special Aocess status with Health Canaca. This list is not endersed by Health Canada's Special Accrss Program. Far precise information about the regulatory status of a drug, contact the Special Acoss Program directly. Entries to the list are nontributed to by several Drug Infarmatian Centres accoss Cansda and by Cansdian drug manufocturers. In cases where nan-marketed drugs do not appear Dn the list, foreign references should be consulted. The content of the list includes generic name and strength/focnoentration, dosage form, pharmamlogy/therapeutic use, trade and code name, source (manufacturer/distriautor), and comments. Avaibhle in English only.

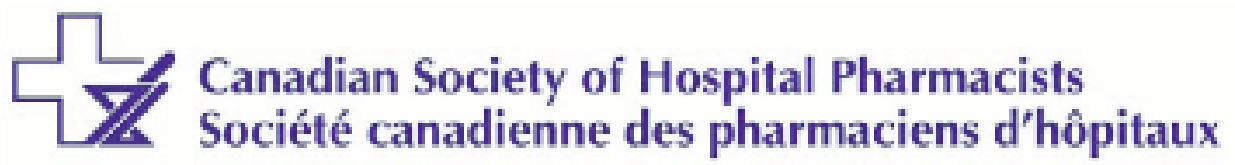

